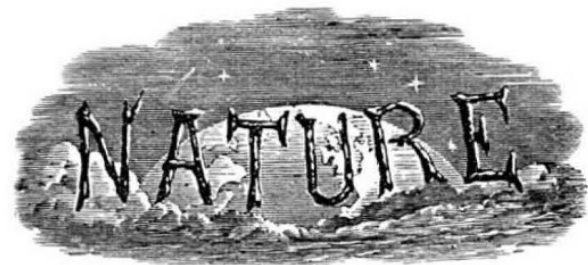

SATURDAY, JUNE 4, I932

\title{
Chemical Warfare and Disarmament
} DDRESSING the House of Commons on May A 13 on disarmament, Sir John Simon, Secretary for Foreign Affairs, said that everyone would agree it was desirable to enter into an agreement, and make effective its observance, against the use of poison gas in warfare. It was an example of 'qualitative' disarmament, contrasted with 'quantitative' disarmament, aiming at a limitation of the number and size of ships and the calibre of guns. Sir John Simon's declaration was received with cheers, and his argument was reinforced in the debate by Mr. Winston Churchill, who laid stress on the indiscriminate character of gas warfare, entailing death and wounds not merely to combatants but also to the civil population, men, women, and children, far removed from the area of hostilities. He pointed out that the acceptance among the leading authorities of different countries of the bombing of open towns would introduce a new idea into warfare, "an idea not compatible with any civilised decency". Are we to allow ourselves to be led, step by step, into contemplating such hideous episodes as part of the ordinary give and take of war?

The question is one with which our chemistsand by the same token our physicists and bacteriologists-who create in their laboratories the raw material, fabrilia fabris, for scientific warfare, are directly concerned, a question which has caused searchings of hearts and consciences, not resolved by ordinary appeals to patriotism. Dr. Delisle Burns's letter published this week in our correspondence columns affords evidence of these misgivings. But it is safe to say that men of science as a whole would not approve of any limitation of the scope and character of scientific research into poisons or any other branch of science which may find application in warfare. No Pope of Geneva must be allowed to compile an index expurgatorius for men of science. "Why, sir," said Dr. Johnson, " that knowledge may, in some cases, produce unhappiness, I allow. But, upon the whole, knowledge, per se, is certainly an object which every man would wish to attain. . . ." Moreover, as Major Lefebure points out in " The Riddle of the Rhine ", if every chemist in the world became a pronounced pacifist, new chemical warfare substances would undoubtedly arise as a normal outcome of research.

It is well to know, however, that the question of disarmament is being studied in all its aspects, officially and unofficially. The report of the InterParliamentary Union on "What will be the Character of a New War?" (P. S. King and Son) includes 
a section on chemical and bacteriological warfare, by Dr. Gertrud Woker, of Switzerland, setting out the general preparations for war, expert views on the effects of chemical warfare, the medical effects of poison gas, and protection of the civilian population. Reference is made to the Report of the American Government on the proposals of the Mixed Committee of the Preparatory Disarmament Commission, in which the view is expressed that the absolute prohibition of training men in the use of chemical weapons in the widest sense would put an end to chemical and medical studies and research, so that such a measure could not possibly be put into practice. In 1924-25, the United States budgeted for an expenditure of $8,700,000$ dollars on chemical defence measures. The great chemical industries, that country asserts, are bound together by their common capital and collaborate to supply each State, under the auspices of the military authorities, with the materials for national defence should the need arise.

Retaliation over enemy territory appears at present to be the only effective defence against chemical warfare in its application to cities. Arming the whole civilian population with masks is, according to one expert, "unthinkable". The provision of ventilated underground refuges is also impracticable. Air manœuvres over London have proved incontrovertibly, we are told, that in the case of serious attack, a great part of London would be destroyed. Of 250 aeroplanes taking part in a night attack, only sixteen were discovered by searchlights. Prof. Langevin has come to much the same conclusion in regard to Paris. He estimates that 100 aeroplanes, each carrying a ton of gas, could in an hour cover Paris with a gas cloud 20 metres thick; and if there were no wind, Paris would be annihilated. Prof. Noel Baker in his book " Disarmament" (1926) says that the "Berlin bombs" prepared for use in the 1919 campaign would have killed every person in the open within 600 to 800 metres of the spot where the bombs exploded.

Progress is continually being made not only in the potency of chemical poisons but also in the art of mixing poisons to produce desired effects. Chlorine, the first gas used, is now superseded because its action is too sudden and its presence in the atmosphere too obvious. Mustard gas, used in the production of indigo, still retains its evil pre-eminence, for no method of counteracting some of its effects has been discovered. Dr. Gertrud Woker concludes her report with a statement that, as things stand at present, war mania would aim only at the complete and unscrupulous destruction of the enemy. "How long ", she asks, " is the flower of each nation, and even every nation as a whole, to be sacrificed to this Moloch?"

Is the picture as black as painted? Is the gloom as unrelieved as even Sir John Simonfor whose aequanimitas in these difficult times the nation has every reason to be grateful--would have us believe? For an answer we may turn to an article by James E. Mills on chemical warfare in the April issue of Foreign Affairs, a quarterly review published by the American Council for Foreign Relations. In reality, he says, the propaganda against it notwithstanding, gas is the most humane weapon existing to-day in actual warfare. $\mathrm{He}$ proves by statistics that the proportion of deaths resulting from gas is far below the general proportion, as 2 per cent to 24 per cent in the case of American casualties. Gas does not mutilate, and it seldom causes extreme pain, those gases which poison without pain being preferred. Its use can be controlled; for example, tear gas will disperse a mob without fatalities unavoidable by the use of machine guns. It is a relatively cheap weapon, and thus makes for equality between large and small nations. "It is possible to assert", he claims, "that the new and powerful weapons of war made possible by science may be a gain to the world." Gas warfare is particularly powerful as defensive weapon, for reasons which will be obviou He thinks the dangers of attacks on cities are over estimated. Omne ignotum pro magnifico!

Research on new poisonous compounds cannot be limited, for they play a necessary part in the development of insecticides, fungicides, germicides, disinfectants, preservatives, fumigants, and drugs. It has been estimated that the destruction caused by insect and animal pests in the United States reaches the astonishing total of more than two billion dollars a year. The bubonic plague in India alone cost $8,000,000$ lives in the first ten years of this century. As becomes a writer who is able to discuss a question in a scientific spirit, $\mathrm{Mr}$. Mills concludes his article with a constructive suggestion. Whether a nation at war under present conditions would drench with poison gas the great cities of an enemy country, with the full knowledge that retaliation would follow, may be left an open question. No objection should be taken, he suggests, to the use of tear gas in war, owing to its non-fatal character. So far as protection can be afforded by treaty, he thinks that the use of poison gas should be allowed only in a nation's own territory as a means of defence. In this way, civilian

No. 3266, VoL. 129] 
populations would be protected, if treaties were observed.

Disarmament must be studied scientificallycoldly and dispassionately, without " laziness, haziness, craziness", surtout without any trace of hysteria. Dr. Cyril Norwood, headmaster of Harrow, in his presidential address last January to the Science Masters' Association, appealed to "scientists" to create a community "which will put spell-binders and slogan-manufacturers of modern politics and journalism out of commission ". We are gratified that our own scientific men, with knowledge and experience, have made contributions to the discussion of disarmament satisfying these criteria. Particularly we would cite Major Victor Lefebure's "Scientific Disarmament: a Treatise on the Facts of Armament", reviewed in NaTURE of April 4, 1931. Our reviewer sounded a note which finds an echo in the present article. "Our failure to grapple with the facts of disarmament", he wrote, "still allows politicians ... to find an easy refuge in moral and economic platitudes." Disarmament, as Major Lefebure insists, is a technical matter, requiring close and continuous study by scientific methods, especially to secure the extension of the 'conversion lag' between the issue of war and the exploitation of the vast resources placed at the disposal of the combatants by science and industry. Science has discovered the poison : it will discover the antidote.

Let us continue our journey, holding the dim taper put into our hands, singing songs of comfort as we go along. May it light us to a world where there shall be no more war between nations-and between people living in the same street! Spellbinders, slogan-manufacturers, schoolmen, babbling sophists merely inspissate the gloom.

\section{W. H. Dines's Scientific Papers}

Collected Scientific Papers of William Henry Dines, B.A., F.R.S. Pp. $\mathrm{x}+461$. (London: Royal Meteorological Society, 1931.) 15s. net.

THE Royal Meteorological Society is to be con1 gratulated on its decision to reprint the scientific papers of Mr. W. H. Dines as a memorial to that eminent meteorologist. The book, which has now appeared, fulfils its purpose admirably and is a credit to the Society as well as an honour to one of its most distinguished fellows. England owes a great deal to its band of amateur men of science, and meteorology probably owes more to the amateur than any other of the major branches of science. Mr. W. H. Dines was an amateur in the best sense of the word. He took up meteorology because it made its own appeal to him, no doubt influenced to some extent by the meteorological work of his distinguished father, Mr. George Dines. This com. pilation of his papers brings home to the reader what a large part Dines played in the development of scientific meteorology in Great Britain; but it also helps those of us who knew the man and read each one of his papers as it appeared to see his work as a whole, and to judge how much of it will be of permanent value and how much of it was laying the foundations on which others have built. It is probably in the last respect that Dines made his greatest contribution to science. Throughout his scientific life Dines was a pioneer; he had the instincts of a pioneer, and the methods of a pioneer. His tools were always of the crudest, without any refinement and without any unnecessary accuracy, but capable of doing the job for which they were designed.

Dines's method of measuring wind pressure by the use of a rotating arm driven by an old secondhand steam engine in the open air will appear crude in the extreme to the worker in a modern aerodynamic laboratory with its wind tunnels and delicate balances; but his method of eliminating the velocity by balancing the wind pressure on the plate against the centrifugal force, both of which depend on the square of the velocity, was a stroke of genius. With this crude apparatus Dines provided data of the wind pressure on plates of different sizes and shapes which were used by engineers and meteorologists until the advent of aviation raised aerodynamics to a separate science. The nine papers on anemometry which form the main part of Section I. of the book are valuable records of the first steps in this new science, although they had all been written before aviation had appeared on the scene as a practical proposition. Most of them, naturally, have now only a historical interest, but it would be well if the younger workers in our aerodynamic laboratories would read them to see what can be done without elaborate instruments.

Towards the end of the nineteenth century meteorologists on the Continent and in America had commenced to investigate the upper atmosphere by means of balloons and kites, but no work was being done in the British Isles. This was largely due to the want of money, for the instruments were expensive and many were lost. This was an unknown country which had a great attraction for Dines's pioneering spirit. He took up kiteflying with great energy. The kites used on the Continent were expensive, fragile structures, so he devised his own kites, which were inexpensive

No. 3266, VoL. 129] 